\title{
The Central Bank Independence in Relation to Inflation and Growth: An Empirical Evidence from Vietnam
}

\author{
Van Hung Dao', The Dong Phung ${ }^{1}$, Khac Lich Hoang ${ }^{2}$, Thi Vinh Ha Nguyen ${ }^{2}$, The Kien Nguyen ${ }^{2, *}$ \\ ${ }^{1}$ Academy of Policy and Development, Hanoi City, Vietnam \\ ${ }^{2}$ VNU University of Economics and Business, Vietnam National University, Vietnam
}

Received November 23, 2021; Revised January 18, 2022; Accepted February 8, 2022

\section{Cite This Paper in the following Citation Styles}

(a): [1] Van Hung Dao, The Dong Phung, Khac Lich Hoang, Thi Vinh Ha Nguyen, The Kien Nguyen, "The Central Bank Independence in Relation to Inflation and Growth: An Empirical Evidence from Vietnam," Universal Journal of Accounting and Finance, Vol. 10, No. 2, pp. 465 - 475, 2022. DOI: 10.13189/ujaf.2022.100211.

(b): Van Hung Dao, The Dong Phung, Khac Lich Hoang, Thi Vinh Ha Nguyen, The Kien Nguyen (2022). The Central Bank Independence in Relation to Inflation and Growth: An Empirical Evidence from Vietnam. Universal Journal of Accounting and Finance, 10(2), 465 - 475. DOI: 10.13189/ujaf.2022.100211.

Copyright $\bigcirc 2022$ by authors, all rights reserved. Authors agree that this article remains permanently open access under the terms of the Creative Commons Attribution License 4.0 International License

\begin{abstract}
Central Bank Independence (CBI) is the ability of a central bank to control monetary instruments. It reflects the set of limits on the Government's influence on managing a central bank's monetary policy. CBI can be restricted or dilated on personnel, objective, policy, and lending aspects. There is quite ample empirical evidence that CBI helps reduce inflation and stimulate growth. However, some countries with high CBI still witness high inflation. This paper seeks to understand when central bank independence would promote inflation control effectiveness. By establishing a mathematical predictive model, the study shows that a certain level of dependence between the central bank and the Government will facilitate the dual goals of price stability and economic growth. The empirical evidence from Vietnam, where the Communist Party leads both entities, reveals the U-shaped relationship between CBI and inflation, but not growth.
\end{abstract}

Keywords CBI, Inflation, Economic Growth, Vietnam

\section{Introduction}

In the 1980s, Central Bank Independence (CBI) emerged as a recipe for avoiding the rampant inflationary consequences of short-sighted electoral ambition [3]. Practical advice, promoted and accepted by international bodies and policymakers [8], was to delegate monetary policies to independent central banks. Many studies show that $\mathrm{CBI}$ was associated with inflation decrease, growth improvement, financial instability, and monetary policy credibility [4, 5, 12, 19, 20, 24, 25, 34]. Walsh[37] used rigorous mathematical demonstrations and proved that delegating monetary policy to the central bank with a contract could eliminate the inflationary bias. Such a contract imposed a penalty on higher inflation, forcing the central bank's governor to opt for eliminating inflationary trends while preserving his(her) full monetary independence. CBI had impacts on monetary policy, fiscal policy coordination, political institutions, democracies, and crisis responses $[1,12,18,21,26,28,30,32,33,35,36$, 38]. However, counterexamples were found in several studies: a high level of independence could increase stock market volatility and contribute to financial instability [27], and central banks with more independence had lesser willingness to prevent financial crises [6].

In Vietnam, the Communist Party leads both the Government and the State Bank, therefore, there is no full central bank independence by institutional regulation. There is a need to investigate CBI versus growth and inflation. The optimal level of the central bank's independence in Vietnam interests politicians from the Communist Party. This paper establishes a mathematical predictive model to look at the convergence of policies between the State Bank and the Government and their dynamics in terms of long-run inflation in Vietnam.

CBI was often identified as the central bank's credibility in implementing monetary policy [2]. Grilli et al.[21] 
realized CBI in terms of political autonomy - the ability of central banks to decide on the final objectives of monetary policy - and economic autonomy - the central bank's operational freedom. Cukierman et al.[14] measured the central bank's independence in personnel, objective, policy, and lending aspects. Personnel independence indicated the restrictions of the Government's influence on the membership or tenure of a central bank's board of directors. Objective independence included the central bank's ability to set targets or select instruments of monetary policy. Policy independence reflected the central bank's authority in formulating and implementing monetary policy. Finally, lending independence limited the Government's ability to use central bank loans to finance its expenditures, avoiding the dependence of monetary policy on fiscal policy. The institutional designs of central banks differed across these dimensions, resulting in different levels of CBI.

Academics broadly believe that a higher degree of central bank independence and a clear mandate to control inflation are essential institutional tools to ensure price stability. Indeed, more than $70 \%$ of central bank reforms worldwide from 1970 to 2012 increased their CBIs [9, 19, 29]. The basic rationale is that the Government favors economic growth and accepts a trade-off with suboptimal inflation. This phenomenon is called "inflation bias." Rogoff[31] proposed delegating monetary policy to an independent and "conservative" central bank to alleviate the inflationary bias. "Conservativeness" means that the Governor of the central bank is more averse to inflation than the Government, so (s)he places more weight on price stability than the Government does.

There was quite ample empirical research on the relationships between CBI and inflation as well as growth [7, 11, 14, 17, 19, 33, 35]. Regressions on the relations between CBI and inflation and growth $[2,19]$ were very sensitive to samples. Cukierman (1994) summarized the empirical findings in the correlation between CBI on the one side and inflation and economic growth on the other side as follows:

(1) In industrialized countries, inflation is negatively correlated with the legitimate CBI indices but not with central governors' turnover ratios.

(2) Among the industrialized countries, the legitimate CBI indices are not correlated with economic growth.

(3) Among the developing countries, the legitimate $\mathrm{CBI}$ indices are not correlated with inflation. However, the turnover ratio is associated with inflation.

(4) Among the developing countries, after controlling for other factors, the turnover ratio is correlated with economic growth, but the legitimate $\mathrm{CBI}$ indices are not.
Since Vietnam is an emerging nation, the two latter points (3) and (4) are likely to apply. However, there was little research on CBI in Vietnam. Huynh (2021) examined the link between Vietnam's CBI and inflation in 1997-2020 and found that inflation was better controlled when CBI was improved.

For China, in the period 1970-1994, like Vietnam, both the Government and the People's Bank of China were led by the Communist Party, the central bank independence was low (0.21). However, its economic achievement and inflation stability were remarkable. China had miraculous economic growth in 1978-1994 and soon became the second-largest economy in the world. From 1994 up to now, China's CBI increased significantly, with higher independence in personnel appointment, target setting, and central bank's policy control. The People's Bank of China has implemented appropriate monetary policies since 1997, which helped this country overcome the world financial crises. The case of China suggests that the optimum level of CBI might be higher if the economy is developed to a certain threshold.

This paper provides a mathematical theoretical model on the CBI's relation with long-term inflation and economic growth in Section 2. The model shows that the relation is non-monotonic. The regression model indicates the empirical evidence in Vietnam. The independence of the State Bank of Vietnam is measured for the period 2013-2020 following the approach of [15]. CBI from 1997-2012 is referred to [19]. The results obtained are presented in Section 3. Section 4 is devoted to conclusions and recommendations.

\section{A Theoretical Mathematical Model}

Let's start with the objectives of the government and the central bank and their loss functions in pursuing their targets. Suppose that capital flows are broadly neutral and that the exchange rate is stable.

First, assume that the government desires to maintain economic growth and seeks to minimize its loss function:

$$
L^{G}=\frac{1}{2} \pi_{t}^{2}+\frac{\alpha}{2}\left(y_{t}-y_{t}^{*}\right)^{2}
$$

in which $\pi_{t}$ denotes the real inflation rate; $y_{t}$ and $y_{t}^{*}$ are real and desired (targeted) output growth rates, respectively; and $\alpha$ is the government's weight on stabilizing output $(\alpha>0)$. The output growth rate is derived from the Lucas supply function (Hof, 1987) as follows:

$$
y_{t}=\pi_{t}-\pi_{t}^{e}+\mu_{t}
$$


in which $\pi_{t}^{e}$ is the expected inflation rate and $\mu_{t}$ is a random shock with zero expectation and variance $\sigma_{\mu}^{2}$. The rational expectation of inflation depends on the available information at the current period.

Taking the first-order condition of (2.1), we obtain:

$$
\begin{aligned}
\frac{\partial L^{G}}{\partial \pi_{t}}=0 & \Leftrightarrow \pi_{t}+\alpha\left(\pi_{t}-\pi_{t}^{e}+\mu_{t}-y_{t}^{*}\right)=0 \Leftrightarrow \\
& \Leftrightarrow(\alpha+1) \pi_{t}=\alpha\left(\pi_{t}^{e}-\mu_{t}+y_{t}^{*}\right)
\end{aligned}
$$

The optimal inflation rate $\pi_{t}$ is derived from (2.3) and written as follows:

$$
\pi_{t}=\frac{\alpha}{\alpha+1}\left(\pi_{t}^{e}-\mu_{t}+y_{t}^{*}\right)
$$

According to (2.4), the inflation rate $\pi_{t}$ to minimize the government's loss function depends on expected inflation $\pi_{t}^{e}$ and desired output growth $y_{t}^{*}$. The equation (2.4) also shows that $\pi_{t}$ is increasing in $\alpha$, which means that if the government takes the output target as its priority, it will lead to higher inflation.

In the long-term, the expected inflation rate equals the actual inflation rate. Formula (2.4) is rewritten as follows:

Taking the expectation of both sides of the equation (2.4) yields the following:

$$
\begin{aligned}
\pi_{t}=\frac{\alpha}{\alpha+1}\left(\pi_{t}-\mu_{t}+y_{t}^{*}\right) & \Leftrightarrow \pi_{t}-\frac{\alpha}{\alpha+1} \pi_{t}=\frac{\alpha}{\alpha+1}\left(y_{t}^{*}-\mu_{t}\right) \\
\text { or } \pi_{t} & =\alpha y_{t}^{*}-\alpha \mu_{t}
\end{aligned}
$$

The first term to the right of the equation (2.6), $\alpha y_{t}^{*}$, is the inflation bias. In many cases, a country with a high inflation bias will face credibility problems, as economic actors recognize that the government encourages unexpected inflation. The second term to the right of the equation (2.6), $\alpha \mu_{t}$, reflects how the output shock affects inflation. To keep price stability, the government needs to reduce its weight on achieving the economic growth target.

From the central bank's side, suppose a "conservative" central bank governor is put in charge of monetary policy. Conservatism means that this governor is more inclined to fight inflation than the government. The central bank's loss function can be written as follows:

$$
L^{C B}=\frac{1+\varepsilon}{2} \pi_{t}^{2}+\frac{\alpha}{2}\left(y_{t}-y_{t}^{*}\right)^{2}
$$

in which $\varepsilon$ indicates the governor's adverse to additional inflation.

A total loss function representing the mixed roles of the central bank and the Government is given as follows:

$$
M_{t}=\gamma L^{C B}+(1-\gamma) L^{G}
$$

in which $\gamma$ denotes the degree of central bank independence, i.e., to what extent the central bank's loss function affects monetary policymaking. If $\gamma=1$ the central bank is utterly determinative of the monetary policy $M_{t}$. Substituting (2.2) into (2.8), we get:

$$
\begin{gathered}
M_{t}=\gamma\left[\frac{1+\varepsilon}{2} \pi_{t}^{2}+\frac{\alpha}{2}\left(y_{t}-y_{t}^{*}\right)^{2}\right]+ \\
+(1-\gamma)\left[\frac{1}{2} \pi_{t}^{2}+\frac{\alpha}{2}\left(y_{t}-y_{t}^{*}\right)^{2}\right]= \\
=\gamma\left[\frac{1+\varepsilon}{2} \pi_{t}^{2}+\frac{\alpha}{2}\left(\pi_{t}-\pi_{t}^{e}+\mu_{t}-y_{t}^{*}\right)^{2}\right]+1 \\
+(1-\gamma)\left[\frac{1}{2} \pi_{t}^{2}+\frac{\alpha}{2}\left(\pi_{t}-\pi_{t}^{e}+\mu_{t}-y_{t}^{*}\right)^{2}\right]
\end{gathered}
$$

The optimal inflation $\pi_{t}$ that minimizes the central bank's loss function can be derived from the first-order condition of (2.9):

$$
\begin{aligned}
& \frac{\partial M_{t}}{\partial \pi_{t}}=0 \\
& \Leftrightarrow \gamma\left[(1+\varepsilon) \pi_{t}+\alpha\left(\pi_{t}-\pi_{t}^{e}+\mu_{t}-y_{t}^{*}\right)\right]+ \\
& \quad+(1-\gamma)\left[\pi_{t}+\alpha\left(\pi_{t}-\pi_{t}^{e}+\mu_{t}-y_{t}^{*}\right)\right]=0 \\
& \Leftrightarrow \gamma\left[(1+\varepsilon+\alpha) \pi_{t}+\alpha\left(-\pi_{t}^{e}+\mu_{t}-y_{t}^{*}\right)\right]+ \\
& +(1-\gamma)\left[(1+\alpha) \pi_{t}+\alpha\left(-\pi_{t}^{e}+\mu_{t}-y_{t}^{*}\right)\right]=0 \\
& \Leftrightarrow \gamma(1+\varepsilon+\alpha) \pi_{t}+(1-\gamma)(1+\alpha) \pi_{t}= \\
& =\gamma \alpha\left(\pi_{t}^{e}-\mu_{t}+y_{t}^{*}\right)+(1-\gamma) \alpha\left(\pi_{t}^{e}-\mu_{t}+y_{t}^{*}\right) \\
& \Leftrightarrow \pi_{t}(1+\varepsilon \gamma+\alpha)=\alpha\left(\pi_{t}^{e}-\mu_{t}+y_{t}^{*}\right)
\end{aligned}
$$

or

$$
\pi_{t}=\frac{\alpha}{1+\varepsilon \gamma+\alpha}\left(\pi_{t}^{e}-\mu_{t}+y_{t}^{*}\right)
$$

Equation (2.10) also shows that if there is a shock, $\mu_{t}>0$, the real inflation will decrease. Vice versa, if $\mu_{t}<0$, the real inflation is higher than the targeted inflation.

We recall the formula (2.4) for minimizing the government's loss function:

$$
\pi_{t}=\frac{\alpha}{\alpha+1}\left(\pi_{t}^{e}-\mu_{t}+y_{t}^{*}\right)
$$

Since $\varepsilon>0$ and $\gamma>0$, comparing (2.4) and (2.10) shows that the central bank's inflation rate will be lower than the government-run inflation rate.

In the long-term, the expected inflation rate equals the actual inflation rate. Formula (2.10) turns out to be as follows:

$$
\pi_{t}=\frac{\alpha}{\alpha+1}\left(\pi_{t}-\mu_{t}+y_{t}^{*}\right)
$$

or

$$
\pi_{t}=\frac{\alpha}{1+\varepsilon \gamma} y_{t}^{*}-\frac{\alpha}{1+\varepsilon \gamma} \mu_{t}
$$


This expression shows that the inflation bias (first term on the right side) is lower for $\varepsilon>0$ and $\gamma>0$, which means that delegating monetary policy to an independent and "conservative" central bank could lower inflation. According to equation (2.11), both central bank independence and inflation aversion are essential. If the central bank governor has the same aversion to inflation as the government (i.e., $\varepsilon=0$ ), the central bank's independence $\gamma$ no longer matters. Similarly, central bank conservatism is unnecessary if the government entirely administers the central bank (i.e., $\gamma=0$ ). There are different combinations of $\varepsilon$ and $\gamma$ that can yield the same results. For each given $\varepsilon=\tilde{\varepsilon}>0$, there exists an optimal value $\gamma^{*} \in(0$, 1) where the loss function reaches its minimum value. Based on the degree of conservatism of the central bank, we can allow the central bank a certain degree of independence so that the loss to society is minimal.

The benefit of the central bank depends on the social loss and the transfer it receives: $U_{t}=T_{t}-L_{t}$ where $U_{t}$ is the benefit of the central bank, $T_{t}$ is the transfer, and $L_{t}$ is the social loss. $L_{t}$ is defined as follows:

$$
L_{t}=\frac{1}{2}\left(\pi_{t}-\pi^{*}\right)^{2}+\frac{\alpha}{2}\left(y_{t}-y_{t}^{*}\right)^{2}
$$

in which $\pi^{*}$ is the targeted inflation.

The transfer $T$ takes the form:

$$
T_{t}=C-\alpha y_{t}^{*} \pi_{t}
$$

where $C$ is a constant. Then, the central bank's loss function will be:

$$
I_{t}=\frac{1}{2}\left(\pi_{t}-\pi^{*}\right)^{2}+\frac{\alpha}{2}\left(y_{t}-y_{t}^{*}\right)^{2}+\alpha y_{t}^{*} \pi_{t}
$$

Differentiating this expression with respect to $\pi_{t}$, we obtain:

$$
\begin{aligned}
& \frac{\partial I_{t}}{\partial \pi_{t}}=0 \\
& \Leftrightarrow\left(\pi_{t}-\pi^{*}\right)+\alpha\left(y_{t}-y_{t}^{*}\right)+\alpha y_{t}^{*}=0 \\
& \Leftrightarrow \pi_{t}=\pi^{*}-\alpha y_{t}=\pi^{*}-\alpha\left(\pi_{t}-\pi_{t}^{e}+\mu_{t}\right) \\
& \Leftrightarrow(1+\alpha) \pi_{t}=\pi^{*}+\alpha \pi_{t}^{e}-\alpha \mu_{t}
\end{aligned}
$$

Then, we get optimal $\pi_{t}$ to minimize the central bank's loss:

$$
\pi_{t}=\frac{\pi^{*}+\alpha \pi_{t}^{e}}{1+\alpha}-\frac{\alpha}{1+\alpha} \mu_{t}
$$

Since $\pi^{*}=\pi_{t}^{e}$, the expression (2.15) is rewritten as follows:

$$
\pi_{t}=\pi^{*}-\frac{\alpha}{1+\alpha} \mu_{t}
$$

Equation (2.16) shows that if there is a shock, $\mu_{t}>0$, the real inflation will decrease. Vice versa, if $\mu_{t}<0$, the real inflation is higher than the targeted inflation.

Substitute (2.16) into (2.2), the output growth function is as follows:

$$
y_{t}=\pi_{t}-\pi^{*}+\mu_{t}=\mu_{t}-\frac{\alpha}{1+\alpha} \mu_{t}=\frac{1}{1+\alpha} \mu_{t}
$$

When the Lucas supply function (equation 2.2) is expanded to maintain output, the supply function will be transformed to the following:

$$
y_{t}=\rho y_{t-1}+\pi_{t}-\pi^{e}+\mu_{t}
$$

in which $\rho \in(0,1)$ is the maintaining parameter.

The long-term social loss function takes the following form:

$$
V=E_{0}\left[\sum_{t=1}^{\infty} \beta^{t-1} I_{t}\right]
$$

where $\beta \in(0,1)$ is the discount rate, and $E_{0}$ is the expected loss at period 0 .

Using the first-order condition of the equation (2.19), the inflation rate that minimizes the loss function is determined as:

$$
\pi_{t}=\pi^{*}+\frac{\alpha y^{*}}{1-\beta \rho-\beta c}-\hat{c} y_{t-1}-\frac{\alpha+\beta \hat{c}^{2}}{1+\alpha-\beta \rho^{2}+\beta c^{2}} \mu_{t}
$$

in which

$$
\hat{c}=\frac{1}{2 \beta \rho}\left[1-\beta \rho^{2}-\sqrt{\left(1-\beta \rho^{2}\right)^{2}-4 \alpha \beta \rho^{2}}\right]>0
$$

According to equation (2.21), the inflation trend depends on the past output growth rate and the targeted one set by the government. If the output growth of the previous year is positive $\left(y_{t-1}>0\right)$, the current year's inflation will decrease. Similarly, if the desired output $y^{*}$ is high, the actual inflation will be higher than the targeted inflation. Once again, the coefficient $\mu_{t}=-\frac{\alpha+\beta \hat{c}^{2}}{1+\alpha-\beta \rho^{2}+\beta \hat{c}^{2}}<0$, so adverse shocks will increase inflation.

\section{Experimental Studies}

There are many researches measuring CBI $[2,12,19$, 21]. Among these, [19] published the most comprehensive dataset of central bank independence (CBI) built on the [15] index (CWN) for 182 countries from 1970 to 2012. This dataset encoded the existence of reforms in 6,764 observations and calculated the CWN index for 5,866 observations.

CWN method of [15] used 16 variables divided into four groups. Group 1 involved terms of office, appointment, dismissal, and holding other positions of the central bank's chief executive officer (CEO) in the government (denoted 
as cuk_ceo). Group 2 related to policy formulation and decision-making when there were conflicting views between the central bank and government agencies in implementing monetary policy and budgeting process (variable cuk_pol). Group 3 reflected the references to the ultimate goal of monetary policy in the central bank law (variable cuk_obj). Group 4 concerned the ability of the public sector to borrow from the central bank, such as limitations on the advances, amounts, terms, interest rates of lending from the central bank to public agencies (variable cuk_limlen). Each of the above sub-variables was given a specific score, as shown in the Appendix. The weights for the components were as follows: CEO 0.2, policy formulation 0.15 , objectives 0.15 , and limitations on lending to the government 0.5 [15].

Table 1 shows the scores of the above four components of Vietnam's CBI from 1997 to 2012 estimated by [19] based on the CWN method. There was no data on CBI from 1996 and earlier in Vietnam.

Cukierman et al.[12] identified cuk_ceo by four sub-variables of Group 1, including CEO's term of office by year, agency appointing CEO, terms related to the dismissal of CEO, and finally, the eligibility of CEO in holding other offices of the Government. Garriga[19] assigned value zero to cuk_ceo, which meant that all four sub-variables in Group 1 had value zero; since the SBV governor's tenure was less than four years, the prime minister assigned the SBV governor, the government decided the discharge of the governor without reason. The Law on the State Bank of Vietnam did not prohibit the governor from having another management position in the governmental offices. Although these scores were assigned correctly following the CWN method, these justifications did not entirely reflect the situation in the Vietnamese context, where the Communist Party had the decisive role in almost all aspects of the economy, and the government did not have overwhelming power over the state bank.

The score on policy formulation independence was also as low as 0.08 . The independent index of the State Bank of Vietnam was relatively low and almost unchanged throughout the period 1997-2012.

The independence index of the State Bank of Vietnam in 2012 was lowest among 179 countries in Garriga's sample. In the research of [2], the CBI of Vietnam ranked $113^{\text {th }}$ among 163 central banks in late 2003.

Following the CWN method (see Appendix 1), the CBI index is calculated for 2013-2020. The scores are shown in Table 2.

Table 1. The State Bank of Vietnam's independence index, from 1997 to 2012

\begin{tabular}{cccccc}
\hline Variable. & cuk_ceo & cuk_pol & cuk_obj & cuk_limlen & \multirow{2}{*}{ CBI } \\
\hline Weight & $\mathbf{0 . 2 0}$ & $\mathbf{0 . 1 5}$ & $\mathbf{0 . 1 5}$ & $\mathbf{0 . 5 0}$ & 0.1492 \\
\hline From 1997 to 2002 & 0 & 0.0825 & 0.40 & 0.1537 & 0.1488 \\
\hline From 2003 to 2012 & 0 & 0.0800 & 0.40 & 0.1537 & \\
\hline
\end{tabular}

Source: Garriga[19]

Table 2. Vietnam's CBIs from 2013 to 2020

\begin{tabular}{|c|c|c|c|}
\hline Group & Variables & Score & Group mean score \\
\hline \multirow{4}{*}{$\begin{array}{l}\text { Chief executive officer } \\
\text { (cuk_ceo) }\end{array}$} & Term of office & 0.5 & \multirow{4}{*}{0.4575} \\
\hline & Who appoints CEO? & 0.5 & \\
\hline & Dismissal & 0.83 & \\
\hline & May the CEO hold other offices in Government? & 0 & \\
\hline \multirow{3}{*}{ Policy formulation (cuk_pol) } & Who formulates monetary policy? & 0.67 & \multirow{3}{*}{0.4900} \\
\hline & Who has the final word in a resolution of conflict? & 0.8 & \\
\hline & Role in the Government's budgetary process & 0 & \\
\hline Objectives (cuk_obj) & Price stability & 0.6 & 0.6000 \\
\hline \multirow{8}{*}{$\begin{array}{l}\text { Limitations on lending to the } \\
\text { government (cuk_limlen) }\end{array}$} & Advances & 0 & \multirow{8}{*}{0.3337} \\
\hline & Securitized lending & 0 & \\
\hline & Terms of lending & 0 & \\
\hline & Potential borrowers from the bank & 1 & \\
\hline & Limits on central bank lending defined in & 0 & \\
\hline & Maturity of loans & 0.67 & \\
\hline & Interest rates on loans & 1 & \\
\hline & $\begin{array}{l}\text { Central bank prohibited from buying or selling government securities in } \\
\text { the primary market? }\end{array}$ & 0 & \\
\hline Average & & & 0.4219 \\
\hline
\end{tabular}

Source: Author's estimation based on CWN method (Cukierman et al. 1992) 
Applying Cukierman's method to Vietnam, the SBV's independence index in the period 2013-2020 is 0.42, which is close to the independence level of US and Canadian central banks. The SBV's independence has improved significantly in all aspects as compared to the period 1997-2012.

Table 3 provides the regression results of inflation and GDP growth on the CBI based on various datasets and samples from [9, 15, 19, 23, 29]. Huynh [23] employs quarterly data for Vietnam, and no lagged values are included. Arnone et al.[2] used ordered probit model for 32 emerging economies. The other models' used annual data of various countries, with the lagged value of output.

Table 3 shows that $\mathrm{CBI}$ has a negative effect on inflation in most studies and pooled samples. Although the relationship between $\mathrm{CBI}$ and growth is generally positive, the relations are not statistically significant in the pooled sample and the sample of CWN. In high-income countries, the association is negative. The relationship between CBI and inflation in Vietnam is negative, based on data collected quarterly from 1990Q1 to 2020Q4 [23].

The mathematical model in section 2 suspects that inflation is not linear to CBI, and too high CBI may not effectively control inflation. A quadratic model of inflation for $\mathrm{CBI}$ is considered.

Using CBI data of Vietnam from 1997 to 2020, the regression models with the dependent variables being inflation and GDP growth, and the independent variables including $C B I$ and $C B I^{2}$ provide the results presented in Table 4.

Table 3. Relationship between CBI and inflation and growth

\begin{tabular}{|c|c|c|c|c|c|}
\hline \multirow[b]{2}{*}{ Model } & \multirow{2}{*}{$\begin{array}{c}\text { Dependent variable } \\
\text { CBI measure (sample) }\end{array}$} & \multicolumn{2}{|l|}{ Inflation } & \multicolumn{2}{|l|}{ GDP growth } \\
\hline & & Coefficient (t-statistics) & $\mathbf{N}$ & Coefficient (t-statistics) & $\mathbf{N}$ \\
\hline 1 & $\begin{array}{l}\text { Garriga } \\
\text { (full) }\end{array}$ & $\begin{array}{c}-174.62 \\
(-4.01)^{* * *}\end{array}$ & 5672 & $\begin{array}{c}.587 \\
(1.02)\end{array}$ & 5474 \\
\hline 2 & $\begin{array}{c}\text { Garriga } \\
\text { (high income) }\end{array}$ & $\begin{array}{c}-26.50 \\
(-3.72) * * *\end{array}$ & 1897 & $\begin{array}{l}-1.310 \\
(-1.73)^{*}\end{array}$ & 1819 \\
\hline 3 & $\begin{array}{c}\text { Garriga } \\
\text { (middle \& lower income) }\end{array}$ & $\begin{array}{c}-329.87 \\
(-4.20) * * *\end{array}$ & 3775 & $\begin{array}{c}3.267 \\
(3.86)^{* * *}\end{array}$ & 3655 \\
\hline 4 & $\mathrm{CWN}$ & $\begin{array}{l}-292.01 \\
(-1.03)\end{array}$ & 1470 & $\begin{array}{l}3.696 \\
(1.10)\end{array}$ & 1364 \\
\hline 5 & $\begin{array}{l}\text { Garriga } \\
\text { (model 4) }\end{array}$ & $\begin{array}{r}-173.85 \\
(-0.70)\end{array}$ & 1470 & $\begin{array}{c}5.307 \\
(2.01)^{* *}\end{array}$ & 1364 \\
\hline 6 & Polillo and Guillen (2005) & $\begin{array}{l}-293.19 \\
(-1.29)\end{array}$ & 985 & $\begin{array}{l}1.993 \\
(1.60)\end{array}$ & 965 \\
\hline 7 & $\begin{array}{l}\text { Garriga } \\
\text { (model 6) }\end{array}$ & $\begin{array}{c}-427.53 \\
(-2.10)^{* *}\end{array}$ & 985 & $\begin{array}{c}2.698 \\
(2.46)^{* *}\end{array}$ & 965 \\
\hline 8 & Bodea and Hicks (2015) & $\begin{array}{c}-241.45 \\
(-3.80) * * *\end{array}$ & 2305 & $\begin{array}{c}1.864 \\
(3.22)^{* * *}\end{array}$ & 2273 \\
\hline 9 & $\begin{array}{l}\text { Garriga } \\
\text { (model 8) }\end{array}$ & $\begin{array}{c}-273.81 \\
(-4.09) * * *\end{array}$ & 2305 & $\begin{array}{c}1.669 \\
(2.77) * * *\end{array}$ & 2273 \\
\hline 10 & $\begin{array}{c}\text { Huynh } \\
\text { (Vietnam) }\end{array}$ & $\begin{array}{c}-116.58 \\
(-4.68) * * *\end{array}$ & 124 & & \\
\hline 11 & $\begin{array}{l}\text { Arnone et al. (2009) } \\
\text { (emerging economies) }\end{array}$ & $0.73 * *$ & 32 & & \\
\hline
\end{tabular}

Source: $[19,2]$.

Table 4. The relationship between CBI and inflation and GDP growth in Vietnam from 1997 to 2020

\begin{tabular}{ccccc}
\hline Dependent variable & Inflation & \multicolumn{2}{c}{ GDP growth } \\
& Coefficient & t-statistics & Coefficient & t-statistics \\
\hline Constant & $\mathbf{4 2 6 6 . 5 3}$ & $\mathbf{2 . 7 2 5 * *}$ & $\mathbf{7 . 6 0 6 2}$ & $\mathbf{1 4 . 1 3 9 * * *}$ \\
$C B I$ & $\mathbf{3 8 6 8 3 . 4 8}$ & $\mathbf{- 2 . 7 2 0 * *}$ & $\mathbf{- 4 . 0 3 7 9}$ & $\mathbf{- 2 . 2 1 5 ^ { * * }}$ \\
$C B I^{2}$ & $\mathbf{6 7 7 5 0 . 8 5}$ & $\mathbf{2 . 7 2 0 * *}$ & & \\
$\mathrm{N}$ & 24 & & 24 \\
$\mathrm{R}^{2}$ & 0.2776 & & 0.1824 \\
\hline
\end{tabular}

Source: Author's calculation 
The coefficients are statistically significant, in which $C B I$ 's coefficient is negative in both models, and $C B I^{2}$ is positive in the inflation model.

Figure 1 indicates that the actual and fitted values of inflation and GDP growth follow the same patterns with their residuals in each model. However, the models can only explain $28 \%$ of the inflation variation and $18 \%$ variation in GDP growth over time.

Figures $2 a$ and $2 b$ indicate that the residuals are not autocorrelated or partially correlated, so the residuals of the two models are stationary. The models are appropriate for further explanation.

The relationship between inflation, GDP growth, and $\mathrm{CBI}$ in Vietnam can be depicted as equations (3.1) and (3.2).

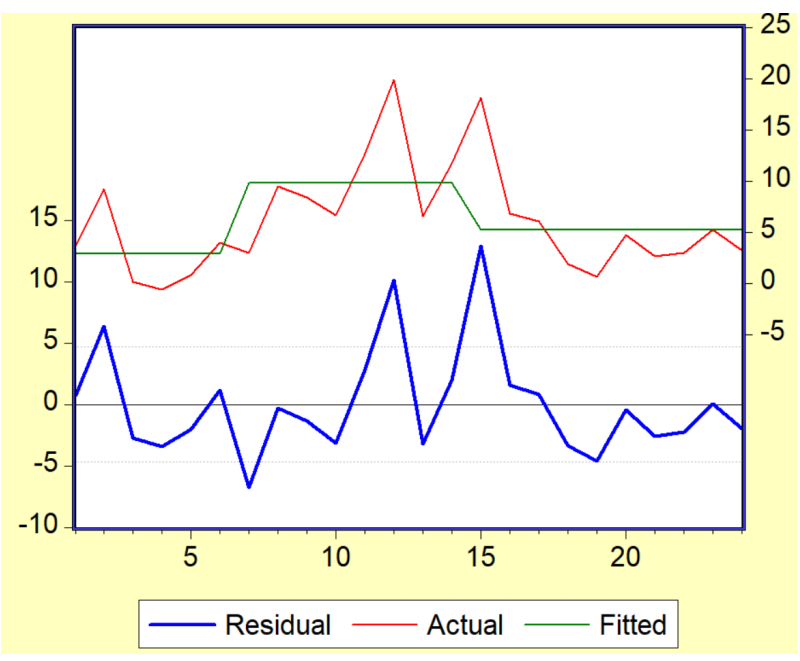

$$
\begin{gathered}
I N F=4266.524862-38683.4796 * C B I+67750.84982 * C B I^{2} \\
(2.725072) * *(-2.720577) * * \quad(2.720165) * * \\
\text { GROWTH }= \\
7.606171483-4.037887835 * \mathrm{CBI} \\
(14.138) * * * \quad(-2.215) * *
\end{gathered}
$$

The values in parentheses ( ) are t-statistics.

The regression results confirm the U-shaped relation between inflation and CBI of the mathematical model. When CBI is low, inflation decreases as the CBI increases, until a certain threshold, inflation increases with higher CBI. The relationship between economic growth and CBI in Vietnam is negative, i.e., the economic growth rate decreases if $\mathrm{CBI}$ is higher.

Actual: INF (GROWTH) observations

Residual $=$ Actual - Fitted INF $($ GROWTH $)$

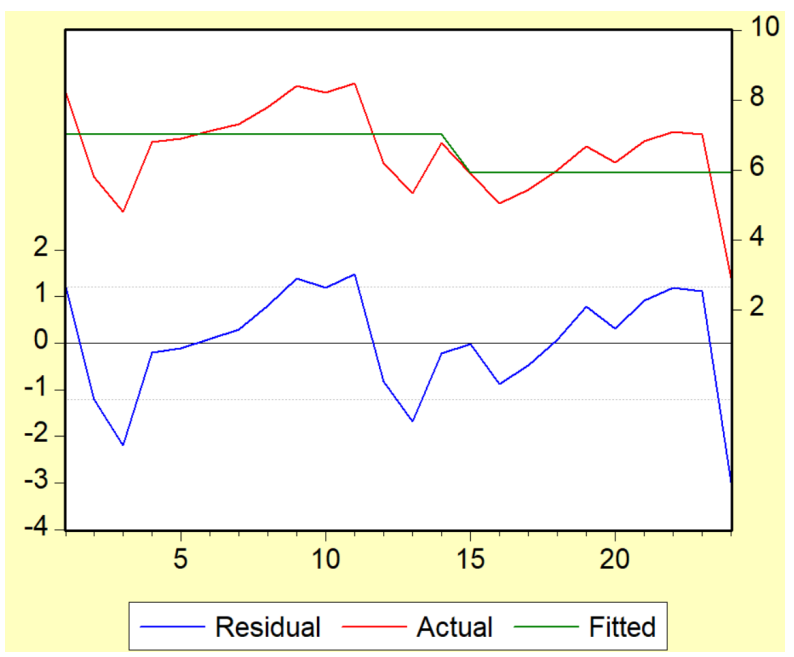

\begin{tabular}{|c|c|c|c|c|c|}
\hline Autocorrelation & Partial Correlation & AC & PAC & Q-Stat & Prob \\
\hline 曰 & １口１ & $\begin{array}{ll}1 & 0.222\end{array}$ & 0.222 & 1.3344 & 0.248 \\
\hline 101 & 101 & $2-0.115$ & -0.172 & 1.7074 & 0.426 \\
\hline 12 & 17 & $3-0.092$ & -0.026 & 1.9615 & 0.580 \\
\hline 17 & 12 & $4-0.098$ & -0.095 & 2.2590 & 0.688 \\
\hline 10 & 10 & $5-0.282$ & -0.278 & 4.8787 & 0.431 \\
\hline 回 & 1 回 & $6-0.310$ & -0.249 & 8.2181 & 0.223 \\
\hline 四 & 1 & $\begin{array}{ll}7 & -0.202\end{array}$ & -0.239 & 9.7113 & 0.206 \\
\hline 17 & ，回 & $8-0.072$ & -0.207 & 9.9126 & 0.271 \\
\hline 1 & ， 回 & $9-0.008$ & -0.231 & 9.9153 & 0.357 \\
\hline 曰 & 17 & $\begin{array}{ll}10 & 0.219\end{array}$ & -0.014 & 12.059 & 0.281 \\
\hline ，巨， & 1 & $\begin{array}{ll}11 & 0.302\end{array}$ & 0.001 & 16.443 & 0.125 \\
\hline ，巨， & 1 & $12 \quad 0.182$ & -0.052 & 18.167 & 0.111 \\
\hline
\end{tabular}

Figure 1. Estimation of INF (left) and GROWTH (right) on CBI.

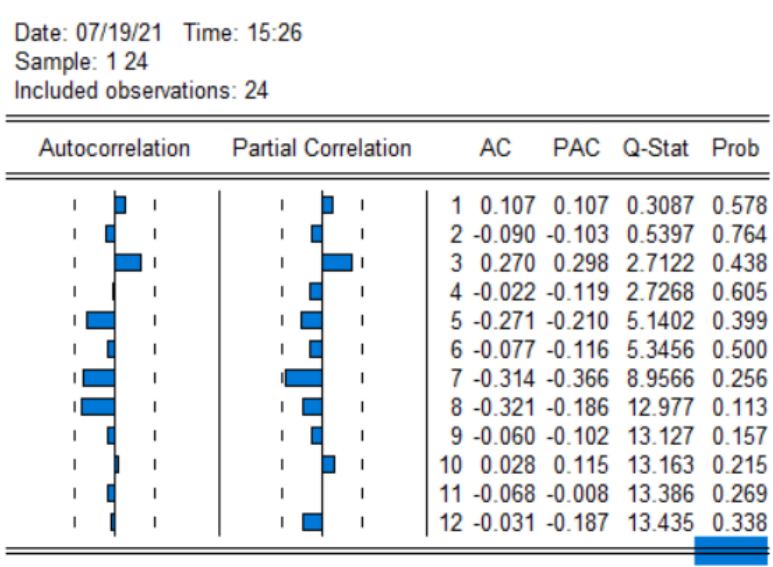

(a) DV: inflation (b) DV: economic growth

Figure 2. Autocorrelation and partial correlation of residuals 


\section{Discussion and Conclusions}

Vietnam's CBI has increased significantly in recent years thanks to the legislative reform and renovation of the State Bank's activities recently. The regression results show a negative relationship between CBI and inflation in the first phase, and when CBI exceeds a certain threshold, it will increase inflation. These findings are consistent with the mathematical model, which implies an optimal independence level of the SBV to ensure inflation control and maintain growth. This finding is also in line with the evidence from several countries [19]. Many countries with high CBI, such as Venezuela, Ecuador, or Guatemala, also have high inflation. The economies continuously fall into crisis and recession. The CBI's of the US and Canada are moderate (0.4804 and 0.4496, respectively), and these countries have well-controlled inflation and maintain economic growth. Therefore, in the context of Vietnam, CBI should be kept at a moderate level.

The research finds that the relationship between economic growth and CBI in Vietnam is negative. Although this result contradicts various studies (Table 4), it is similar to the results of [19] for the group of high-income countries.

The mathematical models in the article show that there should be optimal independence between the Government and the state bank to promote growth and control inflation. Most studies show that a central bank with a high degree of independence will control inflation better. Nevertheless, growth is also essential. For example, there are many mixed opinions about the inflation situation in the case of the United States recently. Some people say that the inflation trend is clear. Some argue that the price level increase is only temporary. However, the Fed policy is that if the US is not fully employed, there is no need to tighten monetary policy, i.e., no inflation control. The same is valid for developing countries like Vietnam, where higher weight is put on growth.

Mathematical formulas also show the dialectical relationship between the central bank and the Government. When the Government and the central bank governor have the same view on anti-inflation, the central bank's independence is no longer meaningful. In Vietnam, the State Bank and the Government have the same goal on economic growth and inflation control, as the Communist Party leads both.

Although the threshold for $\varepsilon$, the coefficient for the optimal degree of dependence between the Government and the central bank, is not identified in this study, there are several implications for Vietnam from the above findings.

(1) The State Bank personnel mechanism remains the same as it is now, decided by the National Assembly.

(2) It is necessary to unify between stabilizing inflation and economic growth and other goals between the Government and the State Bank.

(3) It is necessary to unify monetary policy with a socialist orientation. However, the State Bank is a specialized agency, and it needs to be more independent to manage monetary policy flexibly.

(4) The State Bank needs to be more independent on lending to the Government and handling huge debts from loss-making state-owned corporations to avoid causing uncontrolled inflation, leading to an economic crisis.

(5) The independence of the State Bank should not be too high, as it will increase inflation and drag down growth.

There are a few limitations in this paper that can be studied more in-depth in future research. First, the weights for variable components are fixed in our study. Future studies could vary those weights to check for the robustness of the results. Second, future research could use structural break techniques to study how the relationships between CBIs and inflation or growth change in different periods, e.g. stable periods, crisis periods, etc.

In summary, the State Bank of Vietnam is an agency under the leadership of the Communist Party and the supervision of the National Assembly with relative independence from the Government, with the unity of objectives and personnel with the Government. However, it still needs a certain level of independence in policy formulation and lending rights to the Government. 


\section{Appendix}

Variables for Legal Central Bank Independence [12]

\begin{tabular}{|c|c|c|c|}
\hline Variable Weight & & Description of variable & $\begin{array}{l}\text { Numerical } \\
\text { coding }\end{array}$ \\
\hline \multirow{20}{*}{$\begin{array}{l}\text { Chief executive } \\
\text { officer (cuk_ceo) }\end{array}$} & \multirow{5}{*}{$\begin{array}{l}\text { Term of office } \\
0.05\end{array}$} & Over 8 years & 1.00 \\
\hline & & 6 to 8 years & 0.75 \\
\hline & & 5 years & $0.50 *$ \\
\hline & & 4 years & 0.25 \\
\hline & & Under 4 years or at the discretion of appointer & 0.00 \\
\hline & \multirow{5}{*}{$\begin{array}{l}\text { Who appoints CEO? } \\
0.05\end{array}$} & Board of central bank & 1.00 \\
\hline & & $\begin{array}{l}\text { A council of the central bank board, executive branch, and legislative } \\
\text { branch }\end{array}$ & 0.75 \\
\hline & & Legislature & $0.50 *$ \\
\hline & & Executive collectively (e.g. council of ministers) & 0.25 \\
\hline & & One or two members of the executive branch & 0.00 \\
\hline & \multirow{7}{*}{$\begin{array}{l}\text { Dismissal } \\
0.05\end{array}$} & No provision for dismissal & 1.00 \\
\hline & & Only for reasons not related to policy & $0.83^{*}$ \\
\hline & & At the discretion of central bank board & 0.67 \\
\hline & & At legislature's discretion & 0.50 \\
\hline & & Unconditional dismissal possible by legislature & 0.33 \\
\hline & & At executive's discretion & 0.17 \\
\hline & & Unconditional dismissal possible by executive & 0.00 \\
\hline & \multirow{3}{*}{$\begin{array}{l}\text { May CEO hold other } \\
\text { offices in } \\
\text { Government? } \\
0.05\end{array}$} & No & 1.00 \\
\hline & & Only with permission of the executive branch & 0.50 \\
\hline & & No rule against $C E O$ holding another office & $0.00 *$ \\
\hline \multirow{12}{*}{$\begin{array}{l}\text { Policy formulation } \\
\text { (cuk_pol) }\end{array}$} & \multirow{4}{*}{$\begin{array}{l}\text { Who formulates } \\
\text { monetary policy? } \\
0.05\end{array}$} & Bank alone & 1.00 \\
\hline & & Bank participates, but has little influence & $0.67 *$ \\
\hline & & Bank only advises Government & 0.33 \\
\hline & & Bank has no say & 0.00 \\
\hline & \multirow{6}{*}{$\begin{array}{l}\text { Who has final word in } \\
\text { resolution of conflict? } \\
0.05\end{array}$} & The bank, on issues clearly defined in the law as its objectives & 1.00 \\
\hline & & $\begin{array}{l}\text { Government, on policy issues not clearly defined as the bank's goals or } \\
\text { in case of conflict within the bank }\end{array}$ & $0.80^{*}$ \\
\hline & & A council of the central bank, executive branch, and legislative branch & 0.60 \\
\hline & & The legislature, on policy issues & 0.40 \\
\hline & & $\begin{array}{l}\text { The executive branch on policy issues, subject to due process and } \\
\text { possible protest by the bank }\end{array}$ & 0.20 \\
\hline & & The executive branch has unconditional priority & 0.00 \\
\hline & $\begin{array}{l}\text { Role in the } \\
\text { Government's }\end{array}$ & Central bank active & 1.00 \\
\hline & $\begin{array}{l}\text { budgetary process } \\
0.05\end{array}$ & Central bank has no influence & $0.00^{*}$ \\
\hline \multirow{6}{*}{$\begin{array}{l}\text { Objectives } \\
\text { (cuk_obj) }\end{array}$} & \multicolumn{2}{|c|}{$\begin{array}{l}\text { Price stability is the major or only objective in the charter, and the central bank has the final } \\
\text { word in case of conflict with other government objectives }\end{array}$} & 1.00 \\
\hline & \multicolumn{2}{|c|}{ Price stability is the only objective } & 0.80 \\
\hline & \multicolumn{2}{|c|}{ Price stability is one goal, with other compatible objectives, such as a stable banking system } & $0.60^{*}$ \\
\hline & \multicolumn{2}{|c|}{ Price stability is one goal, with potentially conflicting objectives, such as full employment } & 0.40 \\
\hline & \multicolumn{2}{|c|}{ No objectives stated in the bank charter } & 0.20 \\
\hline & \multicolumn{2}{|c|}{ Stated objectives do not include price stability } & 0.00 \\
\hline
\end{tabular}


Table continued

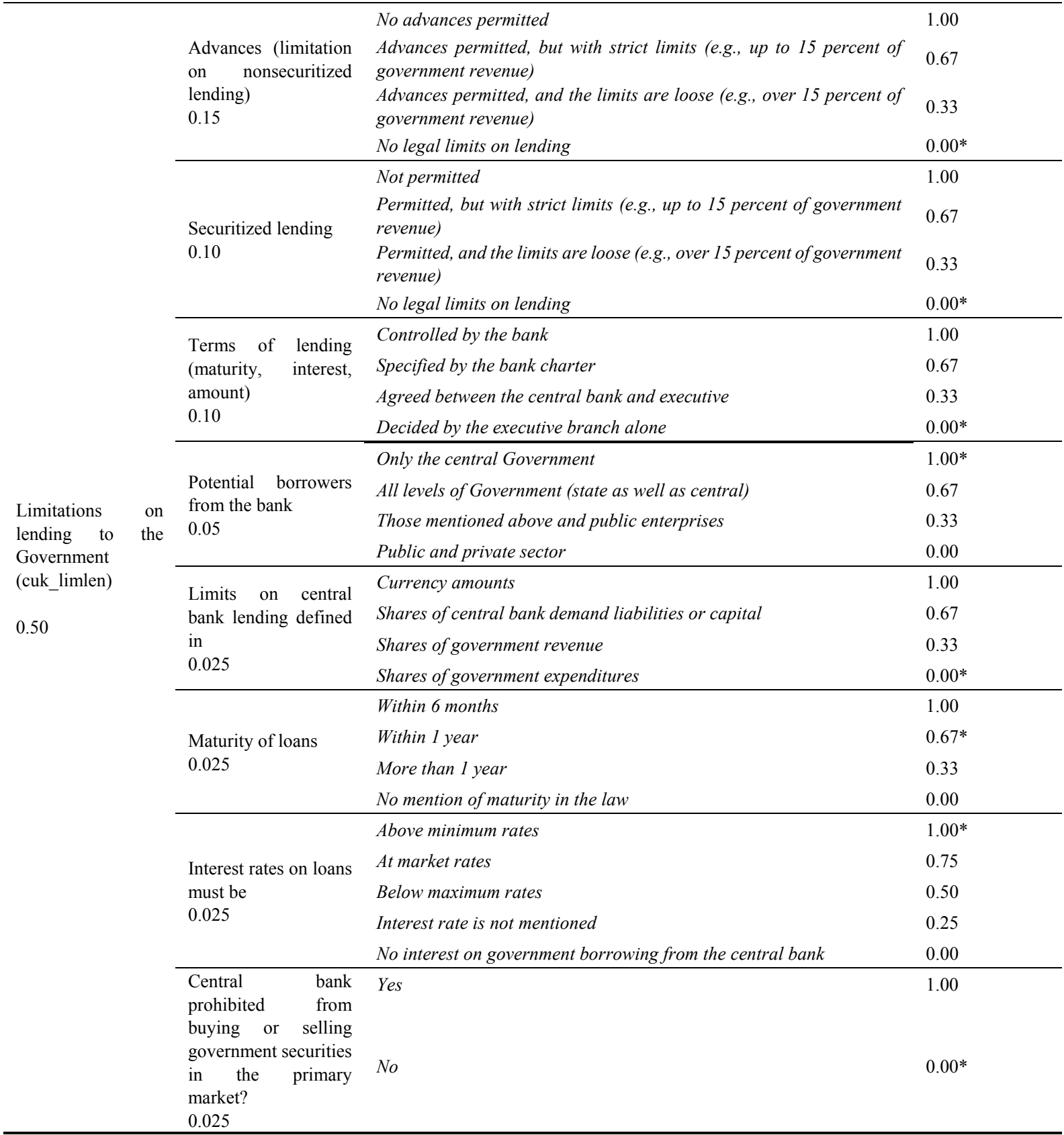

Note: The ranking under each criteria indicates the degree of independence of central banks-the higher the code, the more independent the central bank

[4] Barro, R. J., D.B. Gordon, "A positive theory of monetary policy in a natural rate model," Journal of political economy, vol. 91, no. 4, pp. 589-610, 1983.

\section{REFERENCES}

[1] Adam, A, Manthos, D.D., K. Pantelis, "Are Democratic Governments More Efficient?," European Journal of Political Economy, vol. 27, pp. 75-86, 2011.

[2] Arnone, M., Laurens, B.J., Segalotto, J. F., M. Sommer, "Central bank autonomy: lessons from global trends," IMF Staff Papers, vol. 56, no. 2, pp. 263-296, 2009.

[3] Bagheri, F.M., N. Habibi, "Political Institutions and Central Bank Independence: A Cross-country Analysis," Public Choice, vol. 96, pp. 187-204, 1998.

[5] Berger, H., De Haan, J., S.C. Eijffinger, "Central bank independence: an update of theory and evidence," Journal of Economic surveys, vol. 15, no. 1, pp. 3-40, 2001.

[6] Berger, W., F. Kißmer, "Central bank independence and financial stability: A tale of perfect harmony?," European Journal of Political Economy, vol. 31, pp. 109-118, 2013.

[7] Berggren, N., Sven-Olov, D, H. Jörgen, "Social Trust and Central-Bank Independence," European Journal of Political Economy, vol. 34, pp. 425-39, 2014.

[8] Bernhard, W., Lawrence J.B., and R.C. William, "The 
Political Economy of Monetary Institutions," International Organization, vol. 56, pp. 693-723, 2012.

[9] Bodea, C., "International Finance and Central Bank Independence: Institutional Diffusion and the Flow and Cost of Capital," Journal of Politics, vol. 77, pp. 268-284, 2015.

[10] Clark, W.B., Sona N.G., P. Paul, "Monetary Institutions and the Political Survival of Democratic Leaders," International Studies Quarterly, vol. 57, pp. 556-67, 2013.

[11] Crowe, C., E.M. Ellen, "Central Bank Independence and Transparency: Evolution and Effectiveness," European Journal of Political Economy, vol. 24, pp. 763-77, 2008.

[12] Cukierman, A, "Central Bank Strategy, Credibility and Independence: Theory and Evidence," Cambridge, MA: The MIT Press, 1992.

[13] Cukierman, A, "Central Bank Independence and Monetary Policymaking Institutions - Past, Present, and Future," European Journal of Political Economy, vol. 24, pp. 722-36, 2008.

[14] Cukierman, A., Geoffrey P.M., B. Neyapti, "Central Bank Reform, Liberalization, and Inflation in Transition Economies: An International Perspective," Journal of Monetary Economics, vol. 49, pp. 237-64, 2002.

[15] Cukierman, A., Steven B.W., N. Bilin, "Measuring the Independence of Central Banks and Its Effect on Policy Outcome," The World Bank Economic Review, vol. 6, pp. 353-98, 1992.

[16] Cukierman, A., Kalaitzidakis, P., Summers, L.H., S.B. Webb, S. B. "Central bank independence, growth, investment, and real rates," In Carnegie-Rochester Conference Series on Public Policy North-Holland, vol. 39, pp. 95-140, 1993

[17] Daunfeldt, S., Jörgen H., and L. Mats, "Why Do Politicians Implement Central Bank Independence Reforms?," Atlantic Economic Journal, vol. 41, pp. 427-38, 2013.

[18] Fischer, S., "Central-bank independence revisited. The American Economic Review, vol. 85, no. 2, pp. 201-206, 1995.

[19] Garriga, A.C., " Central Bank Independence in the World: A New Dataset," International Interactions, vol. 42, no. (5), pp. 849-868, 2016.

[20] Garriga, A.C., C.M. Rodriguez, "More effective than we thought: Central bank independence and inflation in developing countries," Economic Modelling, vol. 85, pp. 87-105, 2020.

[21] Grilli, V., Masciandaro, D., G. Tabellini, "Political and Monetary Institutions and Public Financial Policies in the Industrial Countries," Economic Policy, vol. 13, pp. 341-92, 1991.

[22] Hof, F.X., "The Lucas supply function and the feasibility of monetary stabilization policy with rational expectations," Empirica, vol. 14, pp. 227-248, 1987.

[23] Huynh, Q.K. "The long-term equilibrium relationship between central bank independence and inflation in Vietnam," Review of Finance, vol. 2, 2021.

[24] Klomp, J., J. De Haan, "Central bank independence and financial instability," Journal of Financial Stability, vol. 5, no. 4, pp. 321-338, 2009.

[25] Kydland, F.E., E.C. Prescott, "Rules rather than discretion: The inconsistency of optimal plans," Journal of political economy, vol. 85, no. 3, pp. 473-491, 1977.

[26] Mersch, Y, “Central Bank independence revisited," In ERA Forum. Springer Berlin Heidelberg, vol. 18, no. 4, pp. 627-645, 2018.

[27] Papadamou, S., Sidiropoulos, M., E. Spyromitros, "Does central bank independence affect stock market volatility?," Research in International Business and Finance, vol. 42, pp. 855-864, 2017.

[28] Pistoresi, B., Salsano, F., D. Ferrari, "Political institutions and central bank independence revisited," Applied Economics Letters, vol. 18, no. 7, pp. 679-682, 2011.

[29] Polillo, S., F.G. Mauro, "Globalization Pressures and the State: The Global Spread of Central Bank Independence," American Journal of Sociology, vol. 110, pp. 1764-802, 2005.

[30] Reenock, C., Jeffrey K.S., R. Marius, "Legal Institutions and Democratic Survival," The Journal of Politics, vol. 75, no. 30, pp. 491-505, 2013.

[31] Rogoff, K.S., " The Optimal Degree of Commitment to an Intermediate Monetary Target," Quarterly Journal of Economics, vol. 100, pp. 1169-89, 1985.

[32] Rosas, G., "Bagehot or Bailout? An Analysis of Government Responses to Banking Crises," American Journal of Political Science, vol. 50, pp. 175-91, 2006.

[33] Strong, C.O., "Political influence, central bank independence, and inflation in Africa: A comparative analysis," European Journal of Political Economy, no. 102004, 2021.

[34] Valila, M.T., "Credibility of Central Bank independence revisited," International Monetary Fund, 1999.

[35] Vonessen, B., Arnold, K., Mas, R.D.O., C. Fehlker, “ The case for central bank independence: a review of key issues in the international debate," ECB Occasional Paper, no. 2020248, 2020.

[36] Vuletin, G., L. Zhu, “ Replacing a "disobedient” central bank governor with a "docile" one: A novel measure of central bank independence and its effect on inflation," Journal of Money, Credit and Banking, vol. 43, no. 6, pp. 1185-1215, 2011.

[37] Walsh, C.E., "Optimal Contracts for Central Bankers," American Economic Review, vol. 85, no. 1, pp. 150-167, 1995.

[38] Walsh, C.E., "Central bank independence revisited," Economic Papers: A journal of applied economics and policy, vol. 30, no. 1, pp. 18-22, 2011 